\title{
The Sipes' Home Site (41RK603): A Late 18th to Early 19th Century Caddo Site on Martin Creek in Rusk County, Texas
}

Timothy K. Perttula

Heritage Research Center, Stephen F. Austin State University

Follow this and additional works at: https://scholarworks.sfasu.edu/ita

Part of the American Material Culture Commons, Archaeological Anthropology Commons, Environmental Studies Commons, Other American Studies Commons, Other Arts and Humanities Commons, Other History of Art, Architecture, and Archaeology Commons, and the United States History Commons

Tell us how this article helped you.

This Article is brought to you for free and open access by the Center for Regional Heritage Research at SFA ScholarWorks. It has been accepted for inclusion in Index of Texas Archaeology: Open Access Gray Literature from the Lone Star State by an authorized editor of SFA ScholarWorks. For more information, please contact cdsscholarworks@sfasu.edu. 


\section{The Sipes' Home Site (41RK603): A Late 18th to Early 19th Century Caddo Site on Martin Creek in Rusk County, Texas}

\section{Creative Commons License}

\section{(c) (1) \&}

This work is licensed under a Creative Commons Attribution-NonCommercial 4.0 International License 


\title{
The Sipes' Home Site (41RK603): A Late 18th to Early 19th Century Caddo Site on Martin Creek in Rusk County, Texas
}

\author{
Timothy K. Perttula
}

\section{INTRODUCTION}

The Sipes' Home site (41RK603) is an Historic Caddo site on Martin Creek, near Trammel's Trace, about $20 \mathrm{~km}$ from its confluence with the Sabine River (see Figure 1 in Perttula et al., this volume). It is ca. $2 \mathrm{~km}$ downstream from the Martin Lake dam. This site was found and investigated by Buddy C. Jones in the 1950 s or early $1960 \mathrm{~s}$. He obtained surface collections of historic and aboriginal artifacts from the site; there are no available notes concerning this work.

\section{ARTIFACT ASSEMBLAGE}

\section{Faience}

A single rim sherd of faience brune from a plate is in the collections from the Sipes' Home site. Its exterior surface has an iron oxide or manganese-enhanced lead glaze, while its interior has a white tin enamel interior surface as well as blue and black painted lines and circle elements (Figure 1a). It may be from a St. Cloud Polychrome or Rouen Polychrome plate (see Avery et al. 2007:Figures 13-14, 16-18, 28 35), and Avery et al. (2007:Figure 39) also illustrate an unidentified faience brune sherd that is similar from the Jordan-Metoyer site (16NA53), in Natchitoches Parish, Louisiana. This is a post-1790 habitation site (Avery et al. 2007:Table 2). According to Avery et al. (2007:467) faience brune dates between 1770-1800.

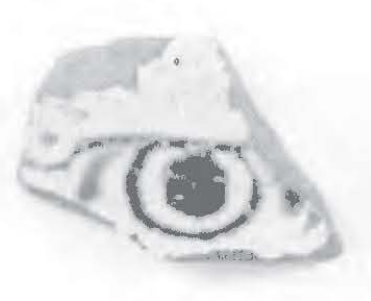

a

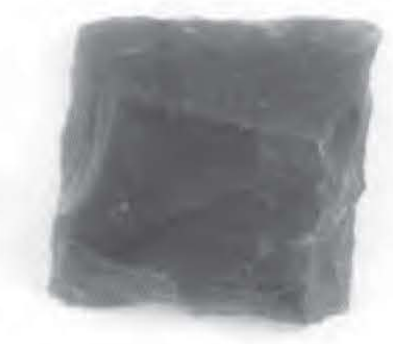

b

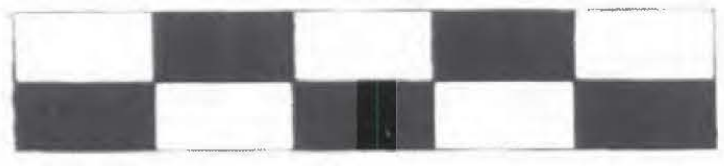

Figure 1, Faience sherd and English blade gunflint from the Sipes' Home site: $a$, faience sherd; $b$, gunflint. 


\section{Refined Earthenwares}

The refined earthenware sheds from the Sipes' Home site $(n=35)$ include plain creamware $(n=3,1762$ 1820 , South 1977), plain and decorated pearlware $(n=17,1780-1820$, Majewski and O'Brien 1987), and decorated whiteware $(n=15$, post $1820 \mathrm{~s})$. The decorated pearlware sherds include one brown-black annular ware body sherd (see Figure 3b, below), blue and green scalloped edge ware ( $n=3)$ (Figure 2), and 10 blue transfer-printed rim and body sherds with oriental and floral motifs (Figure 3). Blue and green scalloped edge pearlware vessels were produced between 1800 and 1820 (Hunter and Miller 2009:13). Among the whitewares there are six blue and green scalloped edge ware rim sherds (ca. 1820s-1840 at the latest) and nine blue transfer-printed rim and body sherds with oriental and floral motifs, as well as a green-yellow hand-painted body sherd (Figure 3a). Blue transfer-printed wares have mean beginning production dates that range from 1817-1834 (Samford 1997:Table 5). The varying proportions of the three wares, particularly the decorated wares, suggest that the Sipes' Home site was likely first occupied by Nadaco Caddo peoples in the late 18 th century, and that occupation probably lasted into the first quarter of the 19 th century.
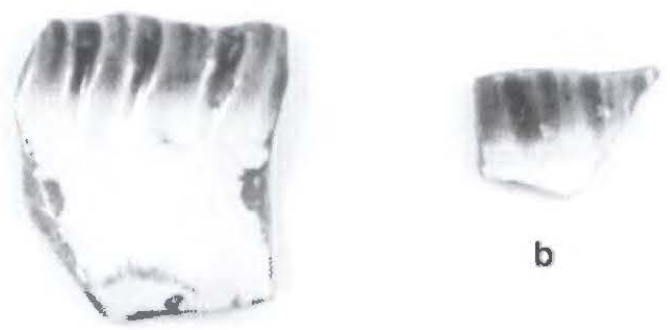

b

a

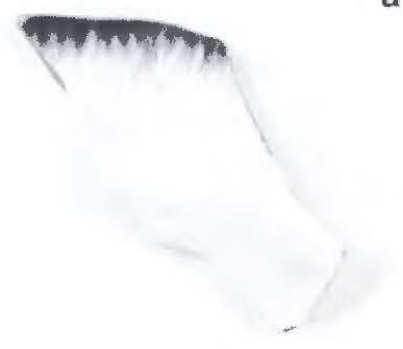

C
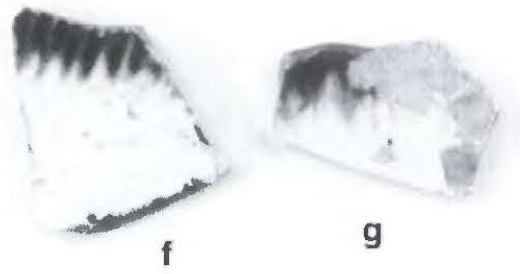

g

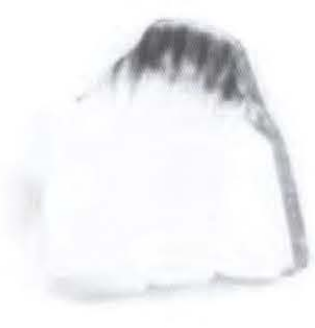

d

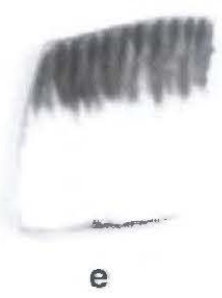

e

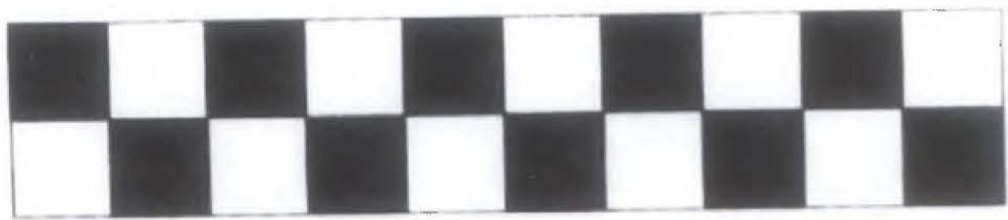

Figure 2. Shell-edged refined earthenware from the Sipes' Home site: a-b, green; c-j, blue. 


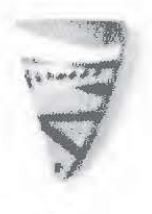

a

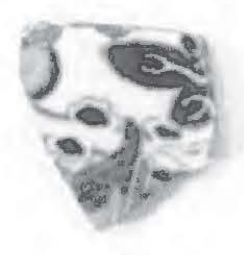

e

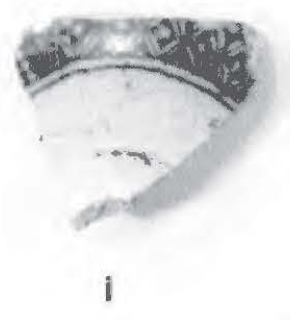

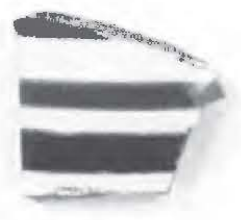

b
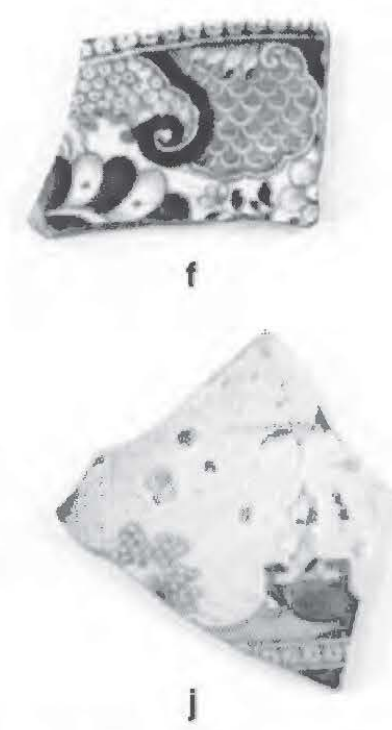

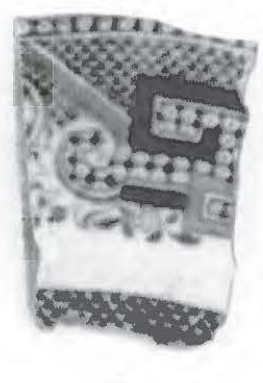

c

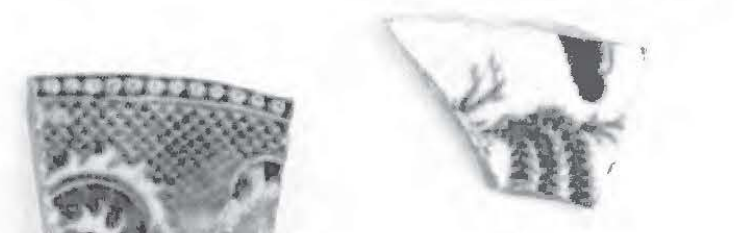

h

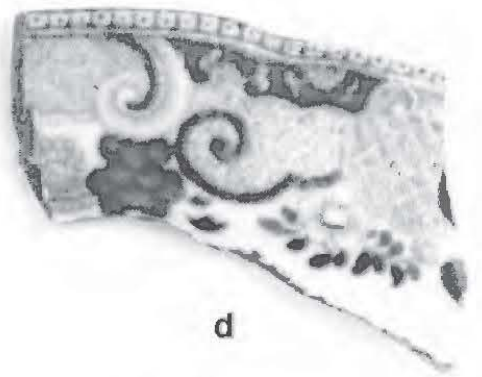

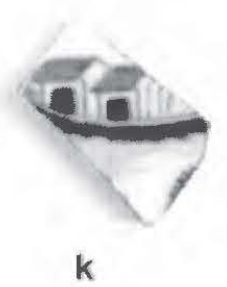

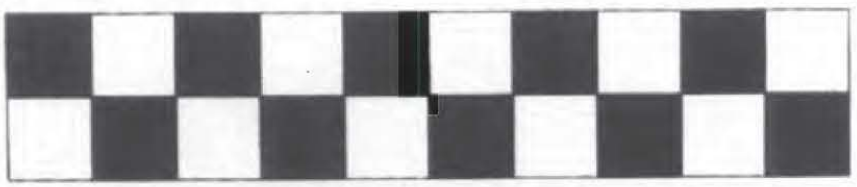

Figure 3. Other decorated refined earthenware from the Sipes' Home site: a, hand-painted; b, annular ware; $\mathrm{c}-\mathrm{k}$, blue transfer-printed.

\section{Kaolin Pipe Bowl and Stem Sherds}

The Sipes' Home site surface collection has three kaolin pipe stems and one kaolin plain pipe bowl (Figure 4). The pipe stems have boreholes with 4/64-inch $(n=2)$ and $3 / 64$-inch $(n=I)$ diameters. These pipe stem bore diameters are consistent with a late 18th-early I9th century age, based on Harrington (1954) histograms, in that pipes with a 4/64-inch bore hole comprised $77 \%$ of a pipe stem sample dating between 1750-1800, and Binford's (1962) regression formula (see discussion in Mallios [2005:90-91]). Binford's formula for pipe stems is:

$$
Y=1931.85-38.26 X
$$

where $\mathrm{Y}$ represents time in years, and $\mathrm{X}$ signifies the pipe assemblage's average bore-diameter measurement. In the small Sipes' Home site sample, the average bore-hole diameter is 3.67. Y is thus 1791.44 , the mean site occupation date, supporting the late 18 th century age of the Caddo component at the site. 


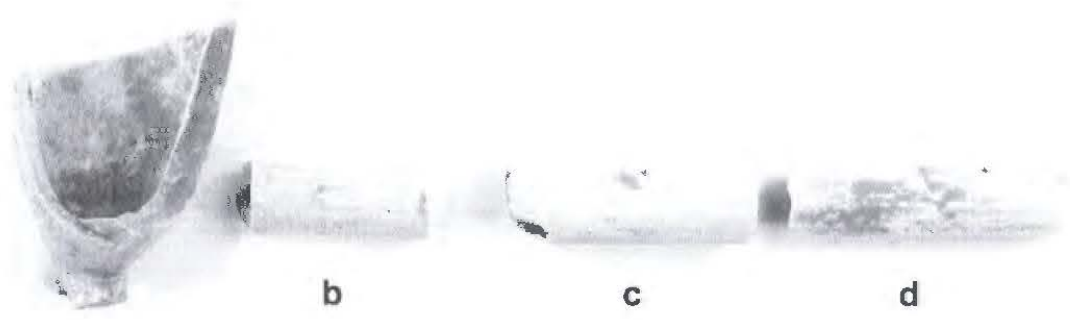

a

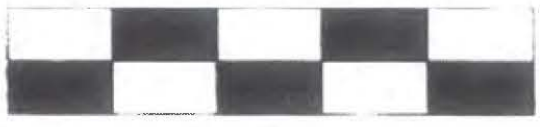

Figure 4. Kaolin pipe sherds: a, pipe bowl; b-d, stem sherds.

\section{Bottle Glass Sherds}

There are five olive green wine bottle glass body or base sherds in the collection. The one base sherd from a late 18th-early 19th eentury hottle (see Jones 2000:157) has a deep pontil (Figure 5).
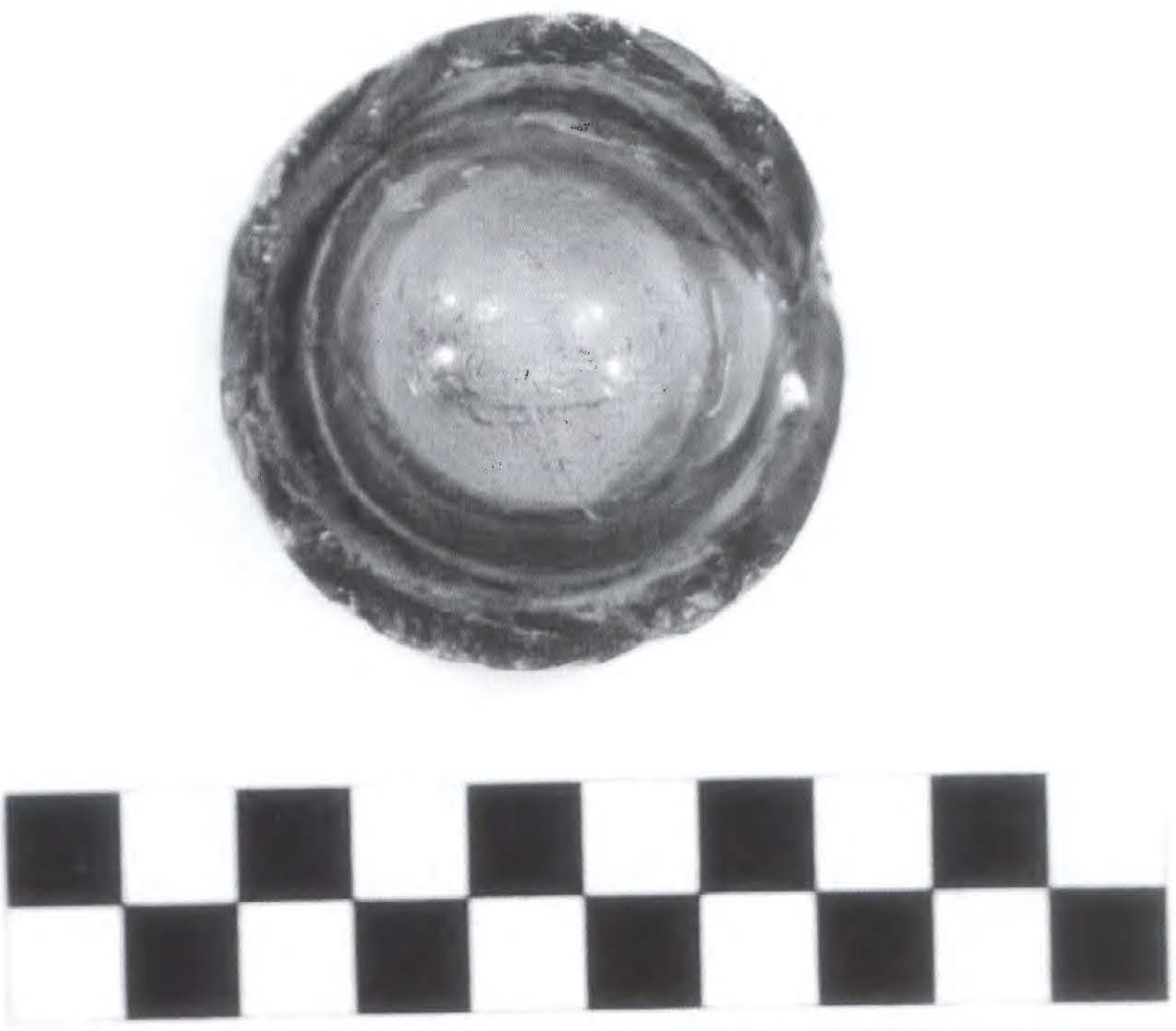

Figure 5. Olive green wine glass base sherd from the Sipes' Home site. 


\section{Gunflint}

The collection from the Sipes' Home site has a single post-1790 black Brandon chert English blade gunflint (see Kenmotsu 2000:343). The gunflint is $20.8 \mathrm{~mm}$ in length, $21.1 \mathrm{~mm}$ in width, and $7.8 \mathrm{~mm}$ thick; there is edge flaking on all four edges (see Figure 1b). Similar English gunflints have been recovered from nearby Martin Creek late 18th century Caddo sites on Trammell's Trace: the Taylor site (4IRK36) (Clark and Ivey 1974:67 and Figure 13e) and Millsey Williamson (4IRK3) (Jones 1968). Clark and Ivey (1974:69) suggest these two sites, as well as others yet to be documented, are part of a late $18^{\text {th }}$ century Nadaco dispersed village or community.

\section{Aboriginal Shell-Tempered Ceramic Sherds}

There are three plain shell-tempered body sherds in the Sipes' Home site collection (Figure 6). These are from thin-walled (mean thickness of $5.5 \mathrm{~mm}$ ) jars that were fired in a reducing environment, but cooled in the open air, leaving oxidized vessel surfaces. Shell-tempered ceramic vessels are rare in East Texas Caddo contexts before the Historic Caddo period (see Perttula et al. 2012), and even when they are present, it is likely that they are from traded/exchanged vessels from Northwest Louisiana, rather than vessels that were made with local clays. At the nearby 18th century Millsey Williamson site (41RK3), 5.5\% of the vessels and $4 \%$ of the sherds were tempered with shell (Perttula and Nelson 2014).
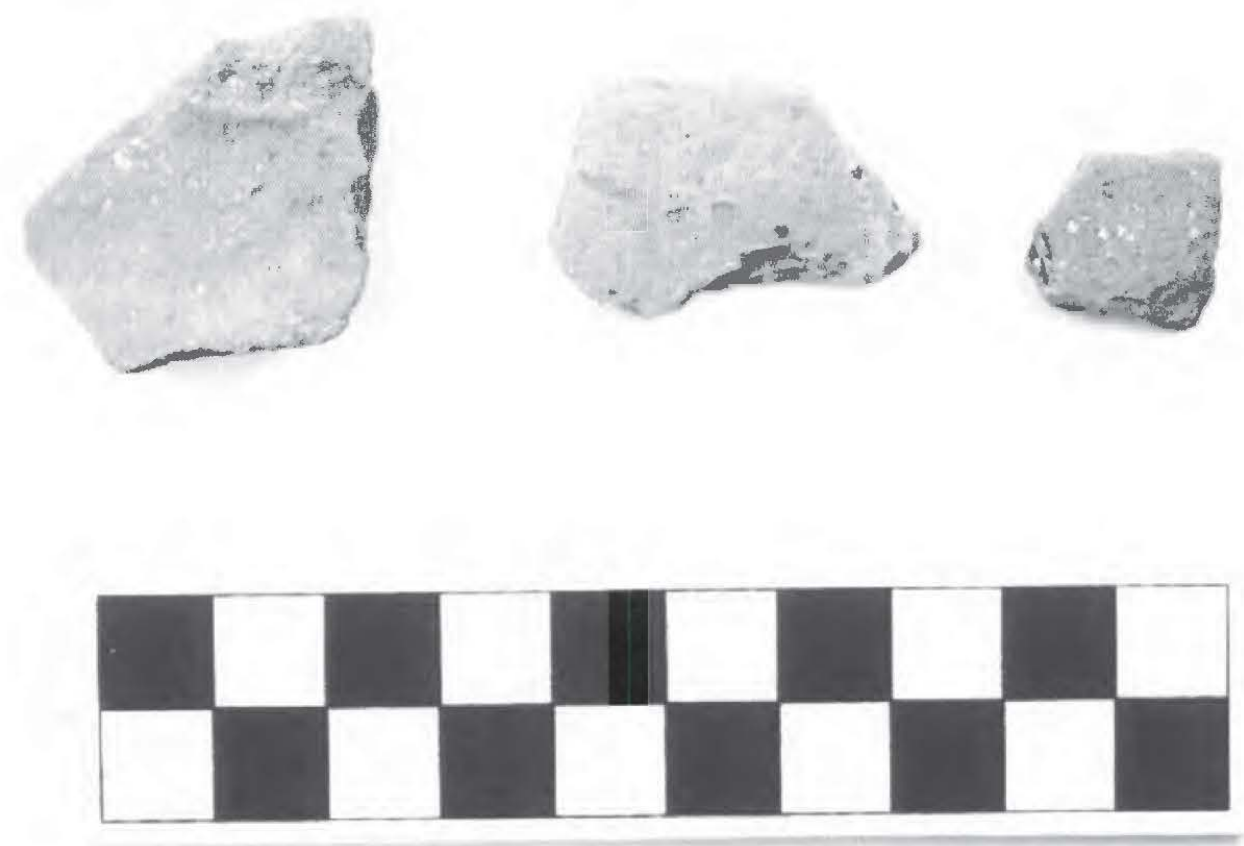

Figure 6. Plain shell-tempered body sherds from the Sipes' Home site.

\section{SUMMARY AND CONCLUSIONS}

The artifact collection from the Sipes' Home site (41RK603) gathered from the surface by Buddy Jones many years ago appears to represent a single component late 18th-early 19th century Caddo settlement near Trammell's Trace and Martin Creek in the East Texas Pineywoods. In addition to both English and French trade goods, including faience brune, refined earthenwares, kaolin pipe stem and bowl sherds, wine bottle glass sherds, and an English blade gunflint being recovered from the site, the Sipes' Home site has aboriginally manufactured shell-tempered ceramic sherds. Given the probable maximum age range of the site, from ca. 1770 to the 1820 s, the Sipes' Home site was a farmstead likely occupied by Nadaco Caddo 
peoples in a larger village community that was dispersed along Martin Creek and Trammell's Trace, an ancient Caddo trail.

\section{ACKNOWLEDGMENTS}

I appreciate the assistance provided by Patti Haskins of the Gregg County Historical Museum in facilitating the study and analysis of the Sipes' Home site collections. Bo Nelsun took the photographic images used in this article.

\section{REFERENCES CITED}

Avery, G., H. F. Gregory, J. Emery, and J. Girard

2007 French Faience in Northwest Louisiana. In French Colonial Pottery: An International Conference, edited by G. Avery, pp. 411-469. Northwestern State University Press, Natchitoches.

Binford. L.

1962 A New Method of Calculating Dates from Kaolin Pipe Stem Samples. Southeastem Archaenlogicul Conference New'sletter 9(1):19-21.

Clark, J. W and J. E. Ivey

1974 Archaeological and Historical Investigations at Martin Lake, Rusk and Punola Counties, Texas. Research Report 32. Texas Archeological Survey, Austin.

Harrington, J. C.

1954 Dating Stem Fragments of Seventeenth- and Eighteenth-Century Clay Tobacco Pipes. Quarterly Bulletin, Archaeological Society of Virginia 9(1):10-14.

Hunter, R. and G. L. Miller

2009 Suitable for Framing: Decorated Shell-Fidge Earthenware. Early American Life, August 2009, pp. 8-19.

Jones. B. C.

1968 The Kinsloe Focus: A Study of Seven Historic Cadduan Sites in Northeast Texas. Master's thesis, Department of Anthropology, University of Oklahoma, Norman.

Jones, $\mathrm{O}$.

2000 Glass Bottle Push-Ups and Pontil marks. In Approaches to Material Culture Research for Historical Archaeologists, $2^{\text {nd }}$ Edition, compiled by D. Brauner. pp. 149-160. The Society for Historical Archacolngy. California. Pennsylvania.

Kenmotsu, N. A.

$2000)$ Gunflints: A Study. In Approuches to Muterial Culture Research for Historical Archaenlogists, $2^{\text {nd }}$ Editiom. compiled by D. Brauner, pp. 340-372. The Society for Historical Archaeology. California. Pennsylvaniat.

Majewski, T.A. and M. J. O’Brien

1987 The Use and Misuse of Nineteenth-Century English and Ameriean Ceramics in Archaeological Analysis. In Advances in Archaeological Method and Theory, Vol. 11, editcd by M. B. Schiffer, pp. 97-209. Academic Press, New York.

Mallios, S.

2005 Back to the BowI: Using English Tobacco Pipebowls to Calculate Mean Site-Occupation Dates. Historical Archaeology 39(2):89-104. 
Perttula, T. K. and B. Nelson

2014 The Millsey Williamson (41RK3), Bead Burial, and L. N. Morwell Farm Sites on Martin Creek: Historic Caddo Settlements along Trammels Trace, Rusk County, Texas. Journal of Northeast Texas Archaeology 44:23-46.

Perttula, T. K., M. B. Trubitt, and J. S. Girard

2012 The Use of Shell-Tempered Pottery in the Caddo Area of the Southeastern United States. Southeastern Archaeology 30(2):242-267.

Samford, P. A.

1997 Response to a Market: Dating English Underglaze Transfer-Printed Wares. Historical Archaeology $31(2): 1-30$.

South, S.

1977 Method and Theory in Historical Archaeology. Academic Press, New York. 